\author{
LOSONCZ, AlPÁr PHD ${ }^{1}$ \\ alpar@uns.ac.rs \\ full professor
}

(University of Novi Sad, Novi Sad, member of Serbian Academy of Sciences and Arts)

\title{
Karl Polanyi in the context of "non-death" of neoliberalism
}

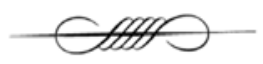

\begin{abstract}
Karl Polanyi's works have been widely thematized regarding the transition in Central and Eastern Europe. The transition was viewed as the "second great transformation". Polanyi's works undoubtedly have numerous followers and it is owing to them that his works have started to be critically interpreted. We are here considering the possibility of reconceptualization of the works after the crisis of neoliberalism. The paper consists of three parts, each focusing on the selected points of Polanyi's work. In the first part, the goal was to confront Polanyi's thought with the consequences of neoliberalism; this part is explicitly involved in politicaleconomic reflection. The second part focuses on the discussion about the meaning of embeddedness, and the third part shows the relevance of some reflexions with respect to the money. The second and third part make a dialogue between political economy and economic sociology, economic anthropology, and economic theory.
\end{abstract}

\section{KEYWORDS}

Polanyi, neoliberalism, embeddedness, money, political-economic reflexivity

DOI 10.14232/belv.2018.4.1 https://doi.org/10.14232/belv.2018.4.1

Cikkre való hivatkozás / How to cite this article: Losoncz, Alpár (2018): Karl Polanyi in the context of "non-death" of neoliberalism. Belvedere Meridionale vol. 30. no. 4. 5-18. pp.

ISSN 1419-0222 (print)

ISSN 2064-5929 (online, pdf)

(Creative Commons) Nevezd meg! - Így add tovább! 4.0 (CC BY-SA 4.0)

(Creative Commons) Attribution-ShareAlike 4.0 International (CC BY-SA 4.0)

www.belvedere-meridionale.hu

\footnotetext{
${ }^{1}$ The article is written under the auspices of the project 179052 supported by the Ministry of Education, Science and Technological Development, Government of the Republic of Serbia.
} 


\section{Confronting With THE STRANGE DYNAMIC OF NEOLIBERALISM}

Over the last decades, there have been such extensive interpretations of neoliberalism that even a Handbook for neoliberalism (SPRINGER - BIRCH - MACLEAVY 2016) was written. However, a consensus on the explanation of neoliberalism has not been achieved. Some explicitly deny the phenomenon, and others present it as metanarration. The 2008 crisis generated an idea that neoliberalism has reached its end, that it has become exhausted, and that we are in a constellation of post-neoliberalism; today, the main issue for discussion is that neoliberalism is persistently and stubbornly being reproduced (CROUCH 2011). We, on the other hand, are neither interested in arguing about the divergence in opinion on neoliberalism, nor discussing about the reasons of existence of neoliberalism.

\subsection{Can Polanyi help us understand neoliberalism?}

As we all know, Polanyi implied that the market system in XIX century did not develop spontaneously; instead, it was an organized, strategic endeavor of the state. We could say that Polanyi offers a radically different causal order: he criticizes the idea that non-intentional market genesis can provide explanation for the economy dynamics; in his opinion, the concept of market must rely on external elements set by the state. In modern language of social sciences, it is obviously a certain kind of ambivalent structure. We can also easily claim that liberal naturalization of the market, the market as self-referential entity is being criticized here.

If the emergence of the market is actually the result of above directed implementation, then affirmation of the market categories provokes opposite reaction of the society; that is Polanyi's famous "double movement". On the one hand, there is a strategically planned involvement of the state highly interested in market implementation, and on the other hand, there is unplanned self-protection of the society that tries to save itself from market destructiveness. This should prevent the emergence of holistic "market society"; the internal resistance of society represents the limit for imposing a market that would thus remain within the framework of "society" as the part of the whole. A well-known historical narrative about Speenhamland, about corrective actions due to derogation of community ties and poverty falls in this category, although this narrative, too, has been interpreted in many and divergent ways (see an influential interpretation, BLOCK SOMERS 1984, 2003).

Polanyi's critical articulation definitely has certain parallels with the ascendance of neoliberal reorganization of society. A historical sequence in Great Britain that Polanyi analyzed, mutatis mutandis, enables the consideration of trends in today's capitalism: Polanyi's generalized point is that market can be created and reproduced with organization and constant non-market control, or paradoxically, with organized and conditioned socio-economic reality. We call it a deep Polanyi-moment. Namely, neoliberalism ideologically emphasizes market-mediated self-organization of the society that enables reduced involvement of the state and entrepreneurship: research have shown the opposite. Instead of entrepreneurship being the "blueprint" for society cohesion, and instead of tendency to consider us all as entrepreneurs who exploit unused market resources ("slack"), there is something else that seem to be dominating, different forms of "rentiership" and "economic rents". 
We should remember that Thomas Piketty's bestseller in certain sense already predicted such a tendency but based on economic data that were not available to Polanyi: he showed that, in the long run, patrimonial aspect dominated in the tension gap between "meritocratic" and "patrimonial" aspects of capitalism.

This can be illustrated with a concrete example. Diversification of rentiership implies state secured forms of rents based on the logic of legal ownership, that is: "neoliberalism is actually characterized by a non-entrepreneurial rationality... concerns the pursuit of housing ownership, housing renovation, and housing speculation...it involves the appropriation of value through government fiat (e.g. laws, regulations, standards), monopoly rights (e.g. location), and organizational reconfiguration (e.g. mortgage securitization). It is not...about the production...rather, it reflects a reliance on unearned income and speculative wealth" (BIRCH 2017. 143).

"Government fiat" and "reregulation" are those who strongly affect the neoliberal situation. "Pro-market orientation": this common and well-known denotation does not explain the dynamics of neoliberalism. After all, we can see that Polanyi's historical description and narration proves one structural fact that the market cannot be perpetuated without systematic non-market interventions. Polanyi would not be surprised if he had to analyze the relationship between the renewned "government fiat" and market, or between the market and forms of ownership organized by a state.

Overcoming the liberal contradiction between state and market Polanyi offers insights not only for the structure but for the genesis of neoliberalism as well. He uses "double-movement" logic to articulate the developing of protective measures for the society: at the same time he claims that there is noncompatibility between market organization and self-protection of the society in the form of social protection (this is his "countermovement"). By even avoiding to analyze different forms of "countermovement", it is clear that Polanyi projects certain structural instability (which he, sometimes, describes as a contradiction between capitalism and democracy).

Polanyi is often described as a welfare-capitalism follower who tends to correct welfare-based measures with respect to the "laissez-faire" capitalism. Still, this description is too simplified and neglects the process related components of Polanyi's thought. He demonstrates the instability of welfare-based capitalism as well, both from historical and theoretical aspects, caused by the structural incompatibility of the logic of social protection and market dynamics. He relentlessly emphasizes the "utopian" elements of economic liberalism, but not even the welfare version of capitalism is spared from the instability. To put it differently, if we turn to Polanyi we can explain why the welfare-based capitalism was realized after the WWII and replaced with neoliberalized capitalism.

Protection from market dynamics is like a double-edged sword to Polanyi: it is a corrective measure which, in the long run, results in malignant effects. This proves not only the obvious fact that Polanyi is still "up-to-date", but it also confirms his relevance regarding the socioeconomic logic of neoliberalism. Yet, not everything can be explained by analyzing Polanyi who still poses some dilemmas.

First, we need to consider that Polanyi's thinking is "ideational"; he attributes strong causal power to the ideas from social changes. Consequently, ideas, for him, give meanings to the organization of society, and this fact explains his energetic engagement in the analysis of different theoreticians. Naturally, Polanyi was not the only theoretician working with such a complex concept of ideas, 
but he was the only one to raise a question with devastating consequences of "utopian", "fictitious" ideas (see, PolAnyi 2012-13, especially, ThOMASBERger 2012). Interestingly, those thinkers who are listed among neoliberalism architects (such as Friedrich Hayek) put ideational approach to the forefront as well: they are all convinced that only the comprehensive conceptual mediation of reality can provide a path to (neo)liberalism. Thus, ideologically prepared hegemony, in the first place, can ensure a true and complete change of society (see, REHMANN 2013. 298.). If we allow ourselves a certain kind of short speculation, then we can say that not only are Polanyi's assumptions about liberal utopia still valid, but they have become especially effective in neoliberalism. Finally, certain approaches to the analysis of neoliberalism emphasize the role of conceptual articulations that, already in the thirties, prepared the transformation of the conceptual field, that is, struggling and agressive "epistemological collectives" (D. Plehwe).

But how are these ideas formed? Is it enough to affirm the ideational approach? Can we explain the rise of economic liberalism, that is, "liberal utopia" by turning to Ricardo and Malthus, or is it that the same utopia is conditioned by other (not ideational) moments? Does the state follow "fictitious ideas"? Does Polanyi may be pay a tribute because he does not have a complex theory of ideology?

Our explanation clearly shows that the state can take dual role: during the implementation of the market, and as an element in the self-defense of the society. The state's involvement is temporally defined, before and after the introduction of a market. However, Polanyi does not clarify the role of the state as a carrier of this double capacity in relation to market dynamics. We can only assume how this problem can be resolved in the absence of an articulated theory of the state.

We also appreciated Polanyi's highly important intellectual contribution to the presentation of a constitutive element of such a non-market subject as the state in the process of creation of a market order. This effect is still of a clear critical significance. At the same time, Polanyi has left us in doubt: if state involved correction aimed at protecting the society is understood as a regulation of the market, then we should be aware of various modes of regulation directed by state. There are even those that have not been established with the purpose of society protection, but to stabilize the market frameworks. We have just discussed the state-based regulation and affirmation of rentiership which proves this because stabilization of "economic rents" requires active involvement of the state or its agencies. In other words, "regulated capitalism" a priori does not destabilize the market order, not even in the long run. Thus, despite our preference for Polanyi's theory, we can see certain drawbacks arising from the unrealized theory of the state.

Furthermore, the problems we have mentioned here and our discomfort with Polanyi turn to be even greater if we take into account that Polanyi gives an incomplete answer to the question that every social science faces; namely, the relation between the social structure and human action, that is, between structurality and subjectivity. If we check the modes of "countermovement" regarding the introduction of the market, we will get an insufficiently articulated picture. "Countermovement" really exists: a researcher who, for example, tries to trace it in some contemporary works, he/she will come across various forms of resistance to austerity-politics in the first and second decade of the 21 st century. Different movements are marked with "countermovement", but with Polanyi, we get the impression that the reaction of society is too 
deterministic in relation to the implementation of the market. In other words, the same reaction appears as deus ex machina in his conceptualization of social dynamics.

Is the defensive self-affirmation of a society in relation to the emerging market an pre-determined process? Does this mean that "countermovement" is a logical shift from a defensive society to a situation where society can put its life under definitive control?

On the other hand, shouldn't social theory be the one to offer some conditions under which subjectivity of resistance would be possible, subjectivity manifested as “collective action"? Is Polanyi's thinking still insufficiently processual, in spite of our appraisal? Isn't this insufficiency the result of undeveloped political-economic configuration?

We should mention another problem in this chapter, although the meanings are related to the following chapter as well. It is about too broad and undefined idea of the market that has been continuously present over a long period of time throughout the history. It should also be noted that in spite of the market being a metaframe today for economic reflection, some theoreticians of social sciences lament "that the market has been little analyzed" and that it functions as a transcendental principle which is often left without concrete explanations (NORTH 1977. 710., MiROWSKI 2016). Is market just a mechanism for supply and demand - although there are only few to defend this reductive interpretation? Is it the place where equilibrium is? Is it a machine for information processing, as believed by Hayek in later years, a machine which operation goes beyond the man's epistemological capacities? Polanyi is not interested in the mediation between exchange and market, which sometimes leaves the impression that he employs these notions as homologous. Eventually, we get a homogenized, poorly biased "market as a monolithic self-consistent phenomenon" (MIROWSKI 2015. 27.). If so, why do we need market as a category at all? Why not stopping at the level of exchange? Even though Polanyi takes us to historical topos where rudimental forms of market are developed, he, too, lacks more elaborated relationship with market.

In fact, we could criticize Polanyi for not making a connection between capitalism and the market. To avoid any long argumentations, here is just a quote: 'his 'static' conception of capitalism fails to identify the way in which the development of capitalism modifies the forms taken by markets... his analysis yielded an inadequate explanation of what guided the pragmatic retreat from the extremes of the market in the mid-twentieth century, with an undue explanatory weight placed upon the contradiction between economics and politics" (DALE 2010. 246., see for comparison, DALE 2016a,b).

Every sentence here is deeply meaningful: Polanyi's theory lacks understanding of structural dynamics of capitalism. Finally, there is poor analysis of articulation between politics and economy, which is a problem that cannot be avoided. We apply rigorous qualification, but should assess Polanyi by taking himself as a criterion. He, indeed, was particularly interested in the said articulation; he constantly emphasized discontent with liberal economic philosophy that was unprepared to explain the dense interaction between economy and politics; moreover, it just (unconsciously) confirms the differences between the two domains. However, even Polanyi failed to succeed in developing political-economic reflection which, in spite of all other contribution, which affected his interpretation of neoliberalism. 


\section{EMBEDDEDNESS: FOR WHAT?}

The category of embeddedness has been several times mentioned in economic sociology which is particularly flourishing in recent times (besides other things, Polanyi has remained one of the most frequently quoted theoreticians in this field, STEINER 2007). Nevertheless, it is interesting to note that the theoretician (Mark Granovetter), who introduced this term in use, did not rely on Polanyi, and this is the reason why some sort of confusion was actually created because his opinion was divergent in relation to Polanyi's. Some interpreters expressed dissatisfaction with the fact that the deformed interpretation of embeddedness led to the incomprehensive analysis of the market, thus reflecting the claims regarding the undifferentiated concept of the market. In fact, it is critically argued that: "Quite paradoxically, the basic intuition that markets are socially embedded - while containing an important insight - has led economic sociologists to take the market itselffor granted" (KRIPPNER 2001. 710., but see, DALE 2010. 198., MIROWSKI 2016). Others criticized the mentioned Granovetter for connecting the analysis with "structuralist network approach" and for making it impossible to understand "social action" (BECKERT 2006, a, b), thus abating the influence of Polanyi's work which, as we have already said, aims at developing political-economic reflexivity. Therefore, Granovetter remains within the frameworks of rational choice methodology, but not Polanyi. We agree with the same criticism.

However, it must be said that Polanyi himself has brought confusion about the meanings of embeddedness. That is to say, he has not clearly conceived the term that is obviously of strategic importance in his vocabulary. Namely, there are certain doubts about it in his work: the mentioned category has hardly been mentioned in the main part (The Great Transformation). In addition, some Polanyi's formulations are contradictory. In some respects, we must play the role of a hermeneutic who tries to understand the author better than he does himself.

In Polanyi's opinion, embeddedness has polemical and political aspects. Polemical aspect of embeddedness criticizes every attempt of economization to separate the sphere of economics from a wider society and promote economics as an un-social sphere. It is suggested that economics/ market is only an integral part of a more complex system so it should be analyzed accordingly. Undoubtedly, Polanyi would see a similar attempt of separating economics from cohesion of society in neoliberalism as well (which was in rudimentary forms present in the $1930 \mathrm{~s}$ of the $20^{\text {th }}$ century, and Polanyi was able to notice it, at least in traces). Furthermore, embeddedness is a political term and Polanyi uses it to oppose to "liberal utopia", that is, he wants "re-embedding" of the market order as politically mediated project. In other words, he wants to restore the economy to its "basic" sources and, in this way, to treat the status of the economy in terms of only relative autonomy that has its own logic but at the same time is an integral part of the society. Finally, the term is critical to economic discourse as well, to the one which treats economization as an hegemonic un-social field. It is unquestionable that Polanyi's approach provides a point of reference for a number of applications that provide valuable conclusions that differ from standard approaches: so, Soviet Union economics can be analyzed in the framework of centralized planning but with all the possible effects of "disembedding" (DALE 2010. 194.). In fact, disembedding is the structural feature of this type of economy.

However, dilemma is still acute. We should bear in mind that Polanyi is a moralist and that moral reflection plays a significant role in his opinions. Moreover, his moralism also has communitarian 
horizons and his reference to famous distinction of Ferdinand Tönnies between Gesellschaft (society) and Gemeinschaft (community) is well known. "Reembedding" also presents certain dynamics of community within a society. The discussion about embeddedness is logical in that context.

However, is embeddedness an ontological term that suggests that embeddedness is a transhistorical characteristic of every market and every economization? Polanyi himself suggests something similar from time to time (Polanyi et al, 1957, see Sobel 2005). At the same time, the suggested concept represents critical intention when it comes to the fact that "liberal utopia" is related to the dynamics of "disembedding", and in this way, capitalism (unlike pre-capitalist societies analyzed by Polanyi) systematically produces "economization" in terms of "disembeddedness". What is the strategic position of the category of embeddedness within the capitalism as "exception" in relation to the said ontological criteria? Some interpreters rightly emphasize the determining role of institution in Polanyi's work: for this reason, we should discuss about "institutional embeddedness". Polanyi's work could be associated with certain tendencies of American institutionalism of Thorstein Veblen, John Commons and others (see, MACOURANT 2001, 2003). On the other hand, other interpreters still believe that it is the special case of "social embeddedness". There are also certain interpreters who believe that Polanyi provokes controversy because he simultaneously develops a "holistic view" (economy as such is transhistorically embedded in the relations of society) and "restrictive institutionalism" (economy as such is reduced to the "socio-spatial patterns in the circulation of goods and services"); embeddedness could be saved as a "methodological principle" in the analysis of economic status (KURTULUS 2008. 7.).

Our argumentation will now take two directions. First, we will list certain moments that additionally hinder the definition of the concept of embeddedness (apart from the problems in terms of market definition); secondly, we will try to reconceptualize the term of political-economic concept.

Therefore, there is a problem of simplified naturalism in Polanyi's work including various texts. Naturally, Polanyi criticized the ideological naturalism presented by classical economists. By analyzing their categories, he subjected them to criticism because of their poor definitions of naturalism. Finally, the entire concept of "constructing" the market is actually the criticism directed to naturalism. However, his work has also been influenced by implicit naturalism. Actually, some aspects of naturalism reach some basic categories, that is, the definition of the economics.

We know that Polanyi devised two definitions of economics, the first one was formal and the second one was substantive by his determination. We are also aware that he devotes his attention to criticizing the formal concept of economics that is seen in "liberal utopia" and in the concept of "self-regulating market". If we discuss about substantive concept, it is obvious that there is a connection with embeddedness: here, Polanyi discusses about economics which, as a part of social system, is regulated by normative and regulative social forms. Production, distribution, consumption, exchange represent constituent parts of economics; man realizes "metabolism" with nature but always in accordance with social patterns. Following the substantive concept, Polanyi has opened the door to economic anthropology (Sahlins, Dalton, Godelier, etc., see, Isaac 2005). By critically emphasizing the formalist concept ("economic fallacy"), Polanyi criticizes various "liberal utopias" that are related to the triad of "scarcity", "market" and "instrumental rationality" (MACOURANT 1993). We can call it a criticism of economization based on formalism that determines the instrumental rationality, that is, calculative rationality by reducing the complex relationships between means and goals, and denying the social determinations of economic categories. 
In his search for universal definition of economization (even the generally accepted one for all social sciences), Polanyi offers the other triad: "nature-needs-institutions". In their friendly criticism, Postel and Sobel (Postel - SoBel 2008) subjected Polanyi to a thorough analysis in an attempt to universalize the relationship between man and nature: in the end, we get replacement of scarcity with material needs in general perspective. Based on the careful analyses of Polanyi's texts, authors criticize Polanyi for not having the developed concept of institution and needs. The author of The Great Transformation and other works uses the category of "material needs", but neglects the fact that "material needs" are also social-historical set of categories. The needs are indeed historically variable with regard to social determinations, but Polanyi neglects that fact or does not attach enough importance to it.

It is particularly important to mention that Polanyi's work is affected by undesirable functionalism: he defines "material needs" using "institutions" and vice versa. Unexpectedly, the institutions are conceptualized as a set of functions that aim at satisfying the universalized material needs. Naturally, Polanyi offers different definitions of institutions (the anthropological definition as well, according to which the institution is a "human project"), but we cannot deny the fact that rest of naturalism is a need. Postel and Sobel suggest the other triad "needs-institutions-practical reason". Naturally, there are different interpretations of Polanyi's intervention in both economic anthropology and economic discourse: there are certain nominalists such as Serge Latouche who decisively reject any "substantive" definition of economics, and they emphasize that there are communities that reject "economics in the same way as they reject the God or state" (LATOUCHE 2004. 476.). This would then mean that not a single substantive definition of economics is adequate. It is not sufficient to insist on the fact that economics in pre-capitalist society has been involved in social forms in advance; it should be said that it does not exist in some communities. Other interpreters try to reduce the influence of "substantivism" in Polanyi's work and offer more exact definitions of economics (CAILLE 2005. 307., SOBEL 2005. 172.). We may think that the analysis of "nature" is very important in Polanyi's work but the relevant analysis has some disadvantages (MIROwSKI 2015).

Here, we should put aside the most important discussion about the relationship between substantive and formalist definition of economics based on Polanyi's work. We are satisfied with the fact that residual "substantivism" prevails in his work. We assume that there is a problem between substantive and formalist definitions of economics and that it has not been resolved yet in Polanyi's work. We also believe that this moment has influence on the dilemma about embeddedness. Isn't it true that embeddedness that goes beyond historical level is exposed to substantivism? Isn't the concept of embeddedness affected by substantivism?

The second part of our discussion leads to the reformation of the concept of embeddedness based on political-economic reflexivity, and we claim that it is in line with Polanyi's opinion. If we regard Polanyi's thesis of embededdness with ontological indication, we will then undermine his approaches. If we complacently state that Polanyi's intervention exacerbates the fact that market economization must have its own legal and cultural prerequisites, starting from the legal state, relevant legal regulations, then we can conclude that Polanyi's work is not thorough and he cannot be distinguished from other theoreticians. Then, we could say that his work is similar 
to the work of different theoreticians who constantly thematize the market conditions that are beyond the economics.

Actually, it should be consistently insisted on polemical and political aspects of embeddedness. Furthermore, it should be persistently insisted on the aforementioned processuality that is a guaranty for development of political-economic reflexivity. Each social-economic formation is characterized by the fact that economic frameworks show certain type of embeddedness, which is the same for capitalism that has its own historically determined modes of embeddedness. However, it is an exception in comparison to the rest of the history because, paradoxally (or dialectically), it affirms embeddedness of market economy based on the mechanism of embeddedness (see similar but not the same formulation, DALE 2010. 202., BLOCK - SOMERS 1985. 65.; therefore, economization is nothing else than the "embedding of the society into the economy"). Embeddedness is the socio-economic form of disembeddedness in capitalism. Mechanisms of the capitalist society are involved in reproduction of this paradoxical constellation.

This way, we could understand the aforementioned dominance of rentiership in neoliberalism that develops its paradoxical forms despite the dominance of market ideology.

Based on Polanyi's work, we can conclude that the degree of embeddedness can only be understood based on the approach that focuses on the analysis of systematic interaction between politics and economics. The modus of embeddedness is politically determined and it is not an expression of a neutral-descriptive articulation. "Liberal utopia" is a phantasmagoria because, by self-determination, its tendency represents (impossible) separation of politics from economics and it is precisely what it denies, the political determination of embeddedness in capitalism.

Finally, at the end of this part: the economic discourse, a critical goal of Polanyi, starts from the fact that legal, ideological and other requirements need to be fulfilled first so that complex market economy could become invigorated. It is only after setting down the mentioned requirements that market economy can start functioning. However, we cannot understand the dynamics of embeddedness based on the previously mentioned. We suggest the other formula that might be consistent with Polanyi: there is simultaneity of conditions and consequences in terms of development of market dynamics. Market economy is neither an output of the previous conditions nor prima causa. Timeliness between the mentioned conditions and dynamics of the economy coincides more with Polanyi and neoliberalism as well.

\subsection{Money as the sign of totality}

Polanyi analyzed money in the above-mentioned main part and his papers on economic anthropology ("primitive" and "archaic money", POLANYI 1957, 1966, 1968). His reflections on money could help us with the configuration of money in neoliberalism, to be more precise, with the financialization phenomenon. In addition, let us consider one important criticism of Polanyi's work regarding money. Actually, the criticism by Viviane ZELIZER (1994, 2000, 2005a,b) centers on the fact that the distinction between embeddedness and disembededdness is inadequate and she finds the balance/interaction rather than constitutive tension between market and society. Money is not only subject to market dynamics and there are specific forms of money that Zelizer calls "earmarking". 
However, let us first see a brief description of the role of money in Polanyi's work (SERVET 1993, 2001), although we do not want to be too extensive because a lot of opinions that have been accepted so far (constitutionality of ideas, ideological articulation, for example) can also be applied here. If we accept our previous remarks regarding political determination of embeddedness, then we can understand the first Polanyi's intervention against traditional economic discourse according to which: a) money is seen as a neutral mechanism, b) money is treated as separated from the so-called real sphere. As we already know, in his articulations, Polanyi analyzes the monetary flows of the 19th century, gold standard, "haute finance" in the same period. Without repeating the details of this description (and without mentioning the problems with consequences of Polanyi's critical analyses of orthodox analyses of money), ${ }^{2}$ we can conclude that money has a strategically important role in The Great Transformation. Polanyi's opinion about money can be analyzed from the aspect of those theoreticians who believe that money is "an expression of social totality" (AglietTA - LoRdon 2007. 242.). Namely, it is certain that Polanyi's non-instrumentalist concept is rather complex and that, in his opinion, money is more than just means of exchange (in his later works, he mentions "payment-money" and "standard of values"). He does not want to equalize money and market; he recognizes the use of money in such societies where market is subordinated. His intention is to show trustworthy but "multifunctional money". ${ }^{3}$ After all, we should bear in mind that the phenomenon of non-market money has been thoroughly described in economic anthropology that examines religious-ritual money in history that coincides with ruler's performance/ calculation, that is, with 'political technology': money is a 'ruling sign', crucial element of "political technology" (OrLEAN 2002, LAUM 1924, 1925, 1992).

"Liberal utopia" or "self-regulating market" cannot be perceived without money as a nonneutral mechanism; we insisted on the concept of embeddedness as a non-neutral mechanism and we apply the same rule in case of money that reorganizes the relationship between state and market. Money is not a commodity here but a "debt-setting" and "accounting practice", except for "means of exchange". Polanyi shows his well-known political polarity ("double movement") in the field of money: he believes that commodity-based ideology of money, which is seen in the legitimacy of the gold standard, had to be the subject of "countermovement" (he even attributes the practice of central bank to this phenomenon). In commodity-mediated money, he sees an ideology that supports "liberal utopia", that is, ideology that causes society resistance.

However, this method is not completely clear and it involves some problems. Polanyi often uses the term "fictive". Namely, "fictive" is particularly used in terms of "fictive commodity", which implies that money, together with work and country, is treated as a "fictive commodity" (Postel - Sobel 2010).

\footnotetext{
2 SAIAg (2014) shows some Polanyi's inconsistencies in relation to orthodoxy: his attitude to barter, especially in his later work, "incomplete break with the dichotomous approach", attitude to accounting, as well as occasional tendency to accepting functionalism in treating money. Simultaneously, we disagree with him when (ibid., 572) he claims that every theory of values (the one which Polanyi rejects) ends in dichotomous distinction between "real" and "monetary" spheres. It seems as if there is no monetary articulation of the theory of values!

${ }^{3}$ SAIAG (2014) emphasizes that there is a close connection between universality of money and multifunctional money in Polanyi's work.
} 
There are certainly critical reasons that justify Polanyi's method: using his triad, he wants to show the impossibility of the mentioned moments to be subjected to the processes of commodification. However, there is a problem here with sharp dichotomy between 'fictive' and 'non-fictive'. It seems that we are again faced with certain type of unreflected "naturalism". Namely, why would only certain commodities be 'fictive' and others are not fictive? How to articulate the demarcation line? We cannot claim that there are 'naturally' determined goods and we should not claim that some things are commodities by nature. Here, we can refer to nominalist criticism of Polanyi but just briefly. In addition, we should address the above-mentioned naturalism because the terms 'fictive' is abundantly used in today's analyses of financialization.

Interestingly, there is a different course in Polanyi's analysis which has barely been noticed and which could be used in more fruitful manner and that is "semantics of money" (POLANYI 1968). We should probably discuss about pragmatic semantics of money because Polanyi strongly emphasizes that the essence of money is understood by the expression "money is what it does". By pointing out the "semantics of money", Polanyi falls into the category of those theoreticians who raise the question of money and language (certain theoreticians believe that there is strong homology between linguistic and monetary referentiality, Goux 1973. 197.), and those who thematize the way the "money talks" (BANDELJ - WHERRY - ZELIZER 2017.). It seems to us that it is the far-reaching exploitation of semantics that enables us to address the problem of 'fictive' money in a better way.

Finally, we have to return to the problem emphasized at the beginning of this part and which seems important for additional clarification of Polanyi's attitude to money. Zelizer is a theoretician whose work focuses on "commercialization of life insurance" and points out the relationship between "intimacy" and money: instead of the game with null-sum, there are different shifts between market/money and society. Zelizer is not satisfied with Polanyi's tendency to reduce the forms of money to monolithic target function ("all-purpose money") because he should be careful when it comes to "pecuniary forms of money" such as "earmarking", which proves that subjective societies do not have to be subjected to money imperialism at all. Actually, as stated by Zelizer, there is no need to be worried because cultural resources are strong enough to withstand the dominance of money that leads to multifunctional money. Accordingly, the expansion of monetary forms implies strengthening of moral identity rather than moral degradation.

We believe that Polanyi's method was not understood here. This criticism affects Polanyi's intentions (let us see STEINER 2009, who allows Polanyi and Zelizer to be right but only in different fields). Zelizer ignores the fact that Polanyi himself wrote in his anthropological works about "multifunctional money" in pre-modern society. He developed the argument of "all-purpose money" because he claimed that there was non-neutral, politically-determined tendency that connected money and "self-regulating market". The fact that money is not neutral means that, in Polanyi's works, functioning of money results in such relations which the said economist-sociologist-anthropologist believes to be deeply problematic. Money is a particularly important medium, means/goal of commodification and it is this constellation of neoliberalism that shows it plausibly. We criticized Polanyi for insufficiently consistent denaturalization and "fictive commodities" but we believe that his work has enough elements for overcoming the abovementioned inadequacies. 


\section{CONCLUSION}

The actuality of Karl Polanyi can be demonstrated in a representative way by

a) economization in neoliberalism as a metaframe for the contemporary epoch,

b) transformation of meanings of embeddedness,

c) dynamic of money.

Taking into account the chosen elements, we analyzed the importance of this work for further studies. Simultaneously, after criticizing the certain tendencies in Polanyi's arguments, we insisted on "rethinking" of his work. We particularly emphasized disadvantages in

a) theory of state and ideology,

b) field of naturalism,

c) disadvantage in relationship between "substantive" and "formalistic" understanding of economics.

Our approach was primarily politically-economically oriented and this was the perspective from which we tried to initiate the discussion about economic anthropology and economic sociology starting from the fact that it was this methodology that was the most adequate for productive arguments against Polanyi.

\section{BIBLIOGRAPHY}

Aglietta, M. - Lordon, F. (2007): Genèse de l'état et genèse de la monnaie: le modèle de la potential multitudinis. In CitTon, Y. - Lordon, F. (eds.): Spinoza et les sciences socials. Paris - Amsterdam. 203-277.

BECKERT, J. (2006a): Interpenetration versus Embeddedness. The Premature Dismissal of Talcott Parsons in the New Economic Sociology. American Journal of Economics and Sociology vol. 65. no. 1. 161-188.

BECKERT, J. (2006b): Was tun? Die emotionale Konstruktion von Zuversicht bei Entscheidungen unter Ungewissheit. In ScherzBerg, A. (ed.): Kluges Entscheiden: Disziplinäre Grundlagen und interdisziplinäre Verknüpfungen. Tübingen, Mohr Siebeck. 123-141.

BIRCH, K. (2017): A Research Agenda for Neoliberalism. Edward Elgar.

Block, F. (2003): In the Shadow of Speenhamland. Social Policy and the Old Poor Law. Politics and Society vol. 3. no. 2. 283-323.

Block, F. - Somers, M. R. (1984): Beyond the Economistic Fallacy. The Holistic Social Science of Karl Polanyi. In Skocpol, Th. (ed.): Vision and Method in Historical Sociology. Cambridge, Cambridge University Press.

CAILlé, A. (2005): Dé-penser l'économique. Contre le fatalism. Paris, La Découverte - M.A.U.S.S. Crouch, C. (2011): The Strange Non-Death of Neoliberalism, Colin Crouch. Malden, MA: Polity. 
DALE, G. (2010): Karl Polanyi. Cambridge, Polity.

Dale, G. (2016a): Karl Polanyi, A Life on the Left. New York, Columbia University Press.

Dale, G. (2016b): Reconstructing Karl Polanyi Excavation and Critique. London, Pluto Press.

Goux, J.-J. (1973): Economie et symbolique. Paris.

IsAaC L. B. (2005): Karl Polanyi. In CARrIER, J. (ed): A Handbook of Economic Anthropology. Northampton, (Mass.), Edward Elgar. 14-25.

KRIPPNER, G. (2001): The Elusive Market: Embeddedness and the Paradigm of Economic Sociology. Theory and Society vol. 30. no. 6. 775-810.

Kurtulus, G. (2008): Karl Polanyi and the Antinomies of Embeddedness. Socio-Economic Review vol. 6. no. 1. 5-33.

LAtouche, S. (2004): Les Limites de L'éclectisme, Pour un relativisme nominaliste. Revue du MAUSS issue 1. no. 23. 474-482.

Laum, B. (1924): Heiliges Geld: Eine Historishe Untersuchung über den Sakralen Ursprung des Geldes, Tübingen, Verlag von J.C.B.Mohr.

Laum, B. (1925): Das Eisengeld der Spartaner. Braunsberg O. P., Verlag der Staatlichen Akademie.

LAUM, B. (1992): Genèse et nature de la monnaie. Extraits du chapitre 5 de Bernhard Laum, Argent sacré. Analyse historique de l'origine sacrée de l'argent, présentés par Alban Bensa, Genèses no. 8. 60-85.

Losoncz, A. (2012): The Interpretation of Crisis from the Spiritual Perspective. In Stark, C. A. Bonner, D.C. (eds.): Handbook on Spirituality. Belief Systems, Societal Impact and Roles in Coping, Maine, Nova Publishers.

Maucourant J. (1993): Monnaie et calcul économique selon K. Polanyi : le projet d'une économie socialiste fédérale. Revue Européenne des sciences sociales vol 31. no. 96. 29-46.

MAUCOURANT J. (2003): Le néo institutionnalisme à l'épreuve de quelques faits historiques, Économie appliquée no. 3. 111-131.

Maucourant, J. (2001): Une lecture de Karl Polanyi. L'Économie politique issue 4. no. 12. 90-106. Mirowski, Ph. (2015): Philip Mirowski, 'Polanyi Vs Hayek?' http://ppesydney.net/philip-mirowskipolanyi-vs-hayek/ (6/28/2018).

MirowsKi, Ph. (2016): This is Water (or is it Neoliberalism?). https://www.ineteconomics.org/ perspectives/blog/this-is-water-or-is-it-neoliberalism (6/28/2018)

Bandelu, N. - Wherry, F. F. - Zelizer, V. A. (2017): Money Talks. Explaining How Money Really Works. Princeton University Press.

OrléAn, A. - Bourdarias, F. (2002): La Monnaie, Opérateur de Totalisation. Journal des Anthropologues no. 90-91. 331-352.

Polanyi LewitT, K. (2012-13): The Power of Ideas: Keynes, Hayek and Polanyi. International Journal of Political Economy vol. 41. no. 4. 5-15. 
Polanyi, K. (1957): The Great Transformation, Boston, Beacon Press.

Polanyi, K. (1957): The economy as instituted process. In Polanyi, K. - Arensberg, C. M. Pearson, H. W. (eds.): Trade and market in the early empires. New York (NY.), Trade Free Press. 243-270.

PolANYI, K. (1966): Dahomey and the slave trade: An analysis of an archaic economy. Seattle (WA.), University of Washington Press.

Polanyi, K. (1968): The semantics of money uses. In Dalton, G. (ed.): Primitive, archaic and modern economies. Essays of Karl Polanyi. New York (NY.), Anchor Books. 175-203.

Polanyi, K. - Arensberg, C. M. - Pearson, H. W. (eds.) (1957): Trade and Market in the Early Empires: Economies in History and Theory. Glencoe (IL), The Free Press.

Postel, N. - SoBel, R. (2008): Économie et Rationalité: apports et limites de l'approche polanyienne. Cahiers d'économie Politique issue 1. no. 54. 121-148.

Postel, N. - Sobel, R. (2010): Le concept de "marchandise fictive", pierre angulaire de l'institutionnalisme de Karl Polanyi? Revue de philosophie économique vol. 11. no. 2. 3-35.

Rehmann, J. (2013): Theories of Ideology., The Powers of Alienation and Subjection. Leiden - Boston.

SAIAG, H. (2014): Towards a neo-Polanyian approach to money: integrating the concept of debt. Economy and Society vol. 43. no. 4. 559-581.

SERVET, J.-M. (1993): L’ institution monétaire de la société selon Karl Polanyi. Revue Economique vol. 44. no. 6. 1107-1150.

SERVET, J.-M. (2001): Le troc primitif, un mythe fondateur d ' une approche économiste de la monnaie. Revue Numismatique vol. 157. no. 6. 15-32.

Sobel, R. (2005): Dé-penser l'économique sans Mauss et avec Polanyi. L'Homme et la société issue 2. no. 156-157. 169-183.

Springer, S. - Birch, K. - MAClEAVY, J. (ed.) (2016): The handbook of neoliberalism. Routledge.

STEINER PH. (2007): Karl Polanyi, Viviana Zelizer et la relation marchés-société. Revue du MAUSS issue 1. no. 29. 257-280.

SteIner, Ph. (2009): Who is right about the modern economy: Polanyi, Zelizer, or both? Theory and Society vol. 38. no. 1. 97-110.

Thomasberger, C. (2012): The Belief in Economic Determinism, Neoliberalism, and the Significance of Polanyi's Contribution in the Twenty-First Century. International Journal of Political Economy vol. 41. no. 4. 16-33.

Zelizer, V. (2000): Fine tuning the Zelizer view. Economy and Society vol. 29. no. 3. 383-389.

Zelizer, V. (2005a): The purchase of intimacy. Princeton, Princeton University Press.

Zelizer, V. (2005b): Circuits within capitalism. In NeE, V. - SwEdBERG, R. (eds.): The economic sociology of capitalism. Princeton, Princeton University. 289-321. 